\title{
Prospects grow brighter for global biosafety agreement
}

Nassau, Bahamas. Representatives of industrialized countries last week indicated that they may be ready to compromise over calls by developing countries for a global biosafety protocol. Signs of a possible compromise emerged during the first Conference of the Parties (COP) to the United Nations (UN) Convention on Biological Diversity agreed in Rio de Janeiro in 1992. (The meeting ends on Friday 9 December.)

The need for a biosafety protocol has been advocated throughout negotiations on the convention by delegates representing China and the so-called Group of 77 (G77), comprising some 132 developing countries. But the proposal has given rise to a vigorous debate between North and South.

According to A. H. Zakri, professor of genetics and plant breeding at the National University of Malaysia in Kuala Lumpur, and a Malaysian delegate to the COP, a global biosafety protocol would be made up of a uniform set of rules governing the environmental release of genetically modified organisms. Zakri points out that although Northern countries already have stringent national guidelines, most developing countries do not yet have the expertise to design such laws. One of the aims of the protocol, he says, would be to ensure that "experiments which are deemed not suitable in the developed countries would not be undertaken in developing countries".

Half-way through the two-week conference, Northern delegations appeared to be moderating their previous positions on this issue. Toshiki Kanamori, director of the Global Issues Division in Japan's Ministry of Foreign Affairs, said "we do not have any objection to initiating the process to consider the need for and modalities of a [global biosafety] protocol".

Echoing this position, Rafe Pomerance, deputy assistant secretary of state for environment and development and head of the US delegation, suggested that such "key international organizations as the UN Industrial Development Organization [UNIDO] and the World Health Organization [WHO] might work to inform the COP on the risks of biotechnology and the release of genetically modified organisms". (As the Senate has not yet ratified the biodiversity convention, the US delegation is attending the Nassau meeting as an observer, and is unable to vote on conference resolutions).

Several delegates, while admitting that the issue of biosafety is a valid concern, pointed out that the introduction of alien species into native ecosystems presents perhaps a greater threat to global biodiversity. Some expressed regret that this issue was not on the agenda of the first COP.

In other areas, the COP was becoming mired in predictable North-South splits. For example, despite widespread consensus that the \$2-billion Global Environment Facility (GEF) administered by the World Bank, the United Nations Development Programme (UNDP), and the United Nations Environment Programme (UNEP) is likely to be the interim funding mechanism to serve the goals of the convention, dissatisfaction with the governance of the GEF was expressed by the G77 and China.

Southern nations are advocating the creation of a new biodiversity fund under the

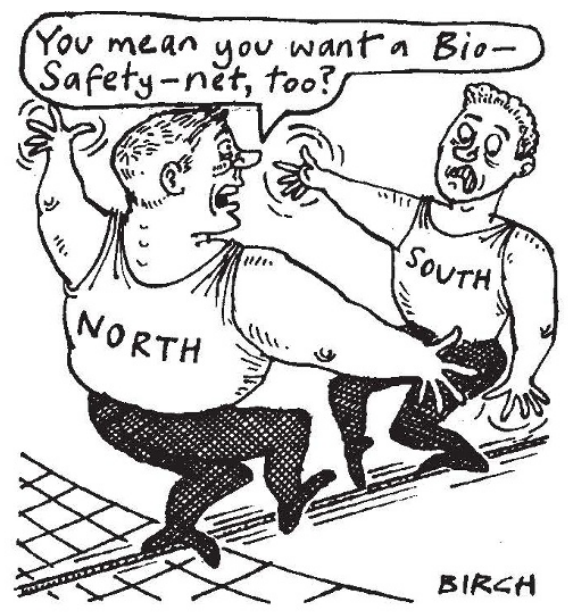

direct authority of the COP, even though in the present GEF arrangement virtually the same group of nations is represented on the GEF council, with power to approve new environmental projects.

There has been further controversy about Article 18 of the convention. This calls for the establishment of a clearing-house mechanism to facilitate technical and scientific cooperation among parties to achieve the convention's goals of biodiversity conservation, the sustainable use of its components and the equitable sharing of benefits arising from the use of genetic resources.

A proposal to provide global brokering services through this clearing-house mechanism in order to promote equitable trading of genetic resources was put forward by the Swedish delegation, and supported by the G77 and China.

Supporters argue that such a service might facilitate access to technology, as called for in the convention, but on a voluntary basis, as insisted on by Northern governments. But the proposal still provoked objections from various Northern countries. These would prefer the function of such a clearing-house mechanism to be limited to providing scientific information.

Daniel Putterman

\section{UK promises level funding for science budget}

London. The British government announced last week that the science budget for 1995 96 will be $£ 1.282$ billion (US $\$ 2.01$ billion) an increase of $£ 40.2$ million on this year. But the award will not provide any growth in real terms, as the increase coincides with the anticipated rate of inflation.

David Hunt, the cabinet minister responsible for science, described the decision, announced as part of the government's general budget plans, as a "good settlement". Furthermore, he said that because of a lower than expected inflation level this year's science budget had grown by 2 per cent in real terms, equivalent to about $£ 31$ million extra.

Robert Hughes, the junior science minister, said that "science has come out again as one of the top priorities". He added that, unlike some of his cabinet colleagues, Hunt had "successfully defended" the science budget by persuading the chancellor, Kenneth Clarke, not to claw back this unexpected bonus.

The new budget has been given a cautious welcome by professional scientific bodies. Sir Michael Atiyah, president of the Royal Society, said he was "pleased" to see that the government "has continued its support for science", and that the settlement "reflects the importance the government attaches to science, technology and engineering in the United Kingdom".

But the pressure group Save British Science (SBS) was less impressed, saying that the sum amounted to "a fudged promise" the prime minister, John Major, had told the Parliamentary and Scientific Committee in February that "we expect spending on the science base to rise in real terms next year, and science will remain a high priority in future".

The group has told the government that in its view a "rise in real terms" should mean at least a 2.5 per cent increase in the science budget for the next financial year over and above inflation. "This is not the response we expect from a serious prime ministerial statement," said John Mulvey, secretary of SBS

John Battle, spokesman for science and technology for the opposition Labour party, also challenged the figures. He is concerned that much of the science budget, distributed to the five main research councils through the Office of Science and Technology (OST), will be used to pay for redundancies. "The government is determined to make staff cuts at the research councils' headquarters [at Swindon in Wiltshire] but the OST needs Treasury money to fund redundancies. If their bid for Treasury money has been successful, millions will be wiped off research and teaching budgets to pay for job losses," claims Battle.
Maggie Verrall 